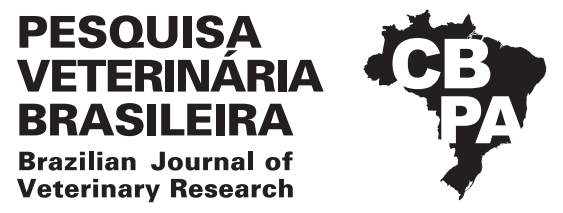

Pesq. Vet. Bras. 39(2):123-128, fevereiro 2019 DOI: 10.1590/1678-5150-PVB-5992

Original Article

ISSN 0100-736X (Print)

ISSN 1678-5150 (Online)

\title{
Spontaneous poisoning by Ricinus communis leaves (Euphorbiaceae) in goats ${ }^{1}$
}

\author{
Luiz B. Brito ${ }^{2}$, Franklin Riet-Correa ${ }^{3}$, Valdir M. Almeida ${ }^{4}$, Givaldo B. Silva Filho ${ }^{5}$, \\ Hisadora A.S. Chaves ${ }^{5}$, Thaiza C. Braga ${ }^{5}$, Joaquim Evêncio Neto ${ }^{5}$ \\ and Fábio S. Mendonça ${ }^{5 *}$ (D)
}

\begin{abstract}
Brito L.B., Riet-Correa F., Almeida V.M., Silva Filho G.B., Chaves H.A.S., Braga T.C., Evêncio-Neto J. \& Mendonça F.S. 2019. Spontaneous poisoning by Ricinus communis leaves (Euphorbiaceae) in goats. Pesquisa Veterinária Brasileira 39(2):123-128. Universidade Federal Rural de Pernambuco, Rua Dom Manoel de Medeiros s/n, Dois Irmãos, Recife, PE 52171-900, Brazil. E-mail: fabio.mendonca@pq.cnpq.br

The aim of this study was to report the clinical and pathological aspects of an outbreak of poisoning by the ingestion of Ricinus communis leaves in a herd of goats at Pernambuco, northeastern Brazil. Within 3-5 hours after ingesting the sprouts and young shrubs of the plant, twenty Toggenburg female goats and two adults crossbred wethers presented acute neurological clinical signs, which were initially characterized by decreased locomotor activity that later evolved to severe ataxia, depression, incoordination and staggering gait. Four goat that died spontaneously were necropsied. Gross lesions were unspecific and consisted in focal areas of lungs edema, petechial hemorrhages in the epicardium and congestion and enlargement of liver. The contents of the rumen, reticulum and omasum were dry and contained leaves of the plant. Histologically there were no lesions in the CNS. In the liver, the main lesion consisted in cytoplasmic vacuolization and necrosis of hepatocytes. Eighteen goats recovered after a supportive therapy with activated charcoal, glycated isotonic solution, dexamethasone and vitamin B12. There is no specific therapy for poisoning by R. communis, however supportive and symptomatic treatments are recommended and should be based on the clinical signs.
\end{abstract}

INDEX TERMS: Plant poisoning, Ricinus communis leaves, Euphorbiaceae, ataxia, depression, ruminants, goats, toxicoses.

RESUMO.- [Intoxicação espontânea por folhas de Ricinus communis (Euphorbiaceae) em caprinos.] 0 objetivo deste estudo foi relatar os aspectos clínicos e patológicos de um surto de intoxicação pelas folhas de Ricinus communis em um

\footnotetext{
${ }^{1}$ Received on August 5, 2018.

Accepted for publication on October 25, 2018.

${ }^{2}$ Post-Graduate Program in Veterinary Medicine, Universidade Federal Rural de Pernambuco, Rua Dom Manoel de Medeiros s/n, Dois Irmãos, Recife, PE 52171-900, Brazil.

${ }^{3}$ Estación Experimental La Estanzuela, INIA, Ruta 50 Km 11, Colonia, Uruguay.

${ }^{4}$ Hospital Veterinário, Centro de Saúde e Tecnologia Rural (CSTR), Universidade Federal de Campina Grande (UFCG), Campus de Patos, Patos, PB 58700-000, Brazil.

${ }^{5}$ Laboratório de Diagnóstico Animal, Departamento de Morfologia e Fisiologia Animal, Universidade Federal Rural de Pernambuco (UFRPE), Rua Dom Manoel de Medeiros s/n, Dois Irmãos, Recife, PE 52171-900. *Corresponding author: fabio.mendonca@pq.cnpq.br
}

rebanho de caprinos em Pernambuco, Nordeste do Brasil. Três a cinco horas após a ingestão dos brotos e arbustos jovens da planta, vinte cabras da raça Toggenburg e dois machos mestiços apresentaram quadro clínico neurológico agudo caracterizado principalmente pela diminuição da atividade locomotora, grave ataxia, depressão, incoordenação e marcha cambaleante. Quatro caprinos morreram espontaneamente e foram necropsiados. Macroscopicamente, as lesões eram inespecíficas e consistiam em áreas focais de edema pulmonar, hemorragias petequiais epicárdicas e aumento do volume e congestão do fígado. Os conteúdos do rumem, retículo e omaso eram ressecados e continham folhas da planta. Histologicamente, não foram observadas lesões no SNC. No fígado, havia vacuolização citoplasmática e necrose de hepatócitos. Dezoito caprinos se recuperaram após receberem terapia de suporte com carvão ativado, soro glicosado, dexametasona e vitamina B12. Não existe terapêutica 
especifica para a intoxicação pelas folhas de R. Communis. Os tratamentos sintomáticos e de suporte são recomendados e devem basear-se nos sinais clínicos.

TERMOS DE INDEXAÇÃO: Intoxicação por plantas, Ricinus communis, Euphorbiaceae, ataxia, depressão, ruminantes, mamona, caprinos, toxicoses.

\section{INTRODUCTION}

Ricinus communis L. (Euphorbiaceae), an upright shrub until 3-4m of high, commonly called castor bean, palma Christi or wonder tree (Worbs et al. 2011, Tokarnia et al. 2012, Albuquerque et al. 2014) is well known for centuries as a toxic plant to both humans and animals (Worbs et al. 2011, Tokarnia et al. 2012). Despite its toxicity, the plant is widely used to produce a variety of products for different purposes: medical, as a laxative or for treatment of infections and inflammation (Poli et al. 2007); industrial, fertilizing and biofuel/biodiesel production (Berman et al. 2011, Lima et al. 2011) and animal feeding with detoxified press cake (Gowda et al. 2009, Diniz et al. 2011).

Ricinus communis contains a complex mixture of toxic substances including the type II ribosome-inactivating ricin, the $R$. communis haemagglutinin and the alkaloid ricinine. Furthermore, other compounds like fatty acids, flavonoids and saponins have been found to exhibit deleterious effects on bacteria, virus, fungi, invertebrates and other animals (Upasani et al. 2003, Bigi et al. 2004, Assis Júnior et al. 2011, Worbs et al. 2011).

In humans, most poisonings are accidental due to consuming unprocessed seeds of $R$. communis (De Paepe et al. 2005, Nishiyama et al. 2005, Lucas 2008, Al-Tamimi \& Hegazi 2008). In animals, most poisonings occur after ingestion of the processed products, although poisoning associated with the consumption of fresh seeds and leaves may also occur (Aslani et al. 2007, Albuquerque et al. 2014, Bianchi et al. 2018). The ingestion of leaves and pericarp causes nervous clinical signs while the ingestion of fruits containing seedscauses digestive disease in ruminants (Albuquerque et al. 2014, Riet-Correa et al. 2017). In Brazil, $R$. communis is often mentioned by farmers as the cause of death, especially for cattle, and was mentioned as an important toxic plant in different epidemiological surveys from the semiarid regions of Pernambuco and Paraíba in the northeastern of the country (Silva et al. 2006, Assis et al. 2009, Mello et al. 2010, Riet-Correa et al. 2017). In cattle, spontaneous poisoning is always associated with intense hunger and, historically, poisonings have occurred on those years of prolonged drought (Albuquerque et al. 2014, Riet-Correa et al. 2017). Data reported until this date were mainly from experimental studies in cattle, sheep and rabbits (Armién et al. 1996, Brito \& Tokarnia 1997, Tokarnia \& Döbereiner 1997) and spontaneous cases of poisoning in goats have not been described.

This study aimed to describe the clinical and pathological aspects of a spontaneous poisoning by Ricinus communis leaves in a goat's herd at Pernambuco, northeastern Brazil.

\section{MATERIALS AND METHODS}

Epidemiological and clinical data of Ricinus communis poisoning in goats were obtained during technical visits in the municipality of Limoeiro, Pernambuco, in northeastern Brazil.

Twenty Toggenburg female goats and two adults' crossbred wethers (castrated males) presented an acute neurological clinical picture. Two female goats and two wethers were selected for a systematized nervous clinical exam performed according to Riet Correa et al. (2002). Their general condition, appetite, color of mucous membranes, rectal temperature, heart and respiratory rates, form of abdomen, and rumen/reticulum motility were recorded. Rumen fluids were also collected to perform laboratory examinations. Examination of rumen fluid was performed according to Dirksen (1993) and Miranda Neto et al. (2005). The pH of the rumen fluid samples was measured at the time of sampling using $\mathrm{pH}$ indicator strips. The color, odor, appearance, sedimentation-flotation, reduction of methylene blue and protozoa activity were analyzed. Density, motility, live-dead ratio and predominance of protozoa were evaluated by direct microscopy (Dehority 1993).

To perform biochemical and blood count tests, blood samples from each goat were collected using a vacuum system through puncture of the jugular vein. These samples were stored in two $10 \mathrm{~mL}$ tubes, one with the anticoagulant ethylenediaminetetraacetate acid (EDTA) in a $10 \%$ aqueous solution and the other without. The serum was separated by centrifugation at $2.500 \mathrm{rpm}$ for 10 minutes and maintained at $-20^{\circ} \mathrm{C}$ until analysis. The biochemical tests were performed using a kinetic process with commercial enzyme kits for aspartate aminotransferase (AST), creatine phosphokinase (CPK), gamma glutamyl transferase (GGT), urea, creatinine and bilirubin (Lopes et al. 2007).

As treatment, it was administered a supportive therapy with orally activated charcoal in a dose of $2 \mathrm{~g} / \mathrm{kg}$ every 6 hours for 24 hours, glycated isotonic solution $5 \%(20 \mathrm{~mL} / \mathrm{kg} / \mathrm{h})$ for three days, a single dose of $1.00 \mathrm{mg} / \mathrm{kg} / \mathrm{IM}$ of dexamethasone and $0.07 \mathrm{mg} / \mathrm{kg} / \mathrm{IM}$ of vitamin B12 every two days totalizing three administrations.

Four goats were necropsied after spontaneous death. Samples of the CNS were obtained from the cerebrum, brainstem, cerebellum, diencephalon and spinal cord. Moreover, fragments of liver, kidney, heart, lung, spleen, rumen, reticulum, omasum, abomasum and intestines were collected, fixed in 10\% formalin, processed routinely, stained with hematoxylin and eosin (HE), periodic acid-Schiff (PAS) and examined microscopically.

\section{RESULTS}

The outbreak of poisoning occurred in a herd of Toggenburg goats from a farm aiming milk production and sale of selected breeding animals. A total of 120 goats composing the herd were raised in a semi-extensive management and few crossbred wethers were also raised. The farm contained feedlots composed by buffel grass (Cenchrus ciliaris) to the goat's graze in the morning and in the afternoon they were removed to stalls to receive fresh water, mineral salt for goats, chopped elephant grass (Pennisetum purpureum) and commercial ration. The farm was located at the Middle Capibaribe Region, municipality of Limoeiro, in the state of Pernambuco, Brazil, in a semi-arid region known as the drought polygon. The rainfall do not exceed $295 \mathrm{~mm}$ in the rainy season and $25 \mathrm{~mm}$ in the dry season, however, presents a drought period less severe than the one on the semiarid region, due to the proximity to the coast. 
On the day of poisonings, some sprouts and young shrubs of Ricinus communis present in the paddock were cut and forgotten by employees on the grazing area. After this, a herd composed by twenty Toggenburg female goats, averaging 4 years of age, and two adults crossbred wethers ate all the withered leaves found on the area and presented acute clinical signs of poisoning. The pasture area was inspected and sprouts of $R$. communis with evidence of being consumed were observed (Fig.1). The goats did not consumed fruits because the shrubs were young and were not in fructification period.

Clinical signs with different levels of intensity developed within 3-5 h after the goats were moved to the area where the plant was left. All goats in this lot were poisoned and more severely affected goats presented dehydration, congestion of episcleral vessels, tachycardia, dyspnea, decreased free locomotor activity until severe ataxia (when standing the goats remained with the limbs crossed) (Fig.2A,B), sialorrhea, depression, constant chewing movements, lateral deviation of head and neck (Fig.2C,D), incoordination, staggering gait, abnormal postures and mild bloat.

Ruminal movements were present but were hypotonic. The main changes observed in ruminal fluid were decreased of methylene blue activity, and slight reduction of the density and motility of rumen microfauna. Hematological abnormalities were mild and consisted of hemoconcentration, slightly increased values of total plasma protein and leukocytosis with neutrophilia in the examined goats. No changes in plasma fibrinogen or serum levels of AST, CPK, GGT, urea, creatinine or bilirubin were identified.

After supportive therapy, eighteen goats recovered totally between 12 to 24 hours after the end of treatment. In two female goats and two wethers the signs progressed to severe depression, sternal recumbency, lateral recumbency and death within 24 hours. Gross lesions in these goats consisted mainly in extensive focal areas of edema on right and left cranial lungs, petechial hemorrhages in the epicardium, congestion and enlargement of liver with a full distended gallbladder and prominent vessels on its surface and the cortical region of the kidneys was pale to yellowish. The contents of the rumen, reticulum and omasum were dry and contained leaves of the plant. In the CNS there was mainly congestion of the leptomeninges blood vessels. These lesions were more pronounced in one goat but were present in all the necropsied goats.

No gross or histologically lesions were found in the central nervous system. In the liver, a diffuse PAS-negative vacuolation of hepatocytes was the main lesion observed. In this case, the hepatocytes had a central nucleus rounded by one, two or three small vesicles into the cytoplasm or a confluent single vesicle. Single necrosis of hepatocytes was also observed and sometimes this lesion was focally extensive. Congestion, edema of Disse's spaces and swollen hepatocytes were also observed diffusely. In the lungs, the main lesion was alveolar edema.

\section{DISCUSSION AND CONCLUSION}

In this outbreak the history of consumption of Ricinus communis and the observation of partially digested leaves in the rumen content were an important factor for the diagnosis of poisoning, because the clinical picture, gross macroscopy and histological lesions are nonspecific (Worbs et al. 2011). Other poisonings like that caused by urea and cyanogenic plants must be considered as differential diagnosis when animals present sialorrhea, muscular tremors, staggering gait and a quick death (Tokarnia et al. 2012).

The clinical picture reported in urea poisoning also include nystagmus, incoordination and pushing against obstacles. These signs arise due to the high concentration of ammonia in the brain and causes neuronal degeneration and spongy degeneration of the neuropils (Visek 1984). While in the poisoning by cyanogenic plants, cyanide inhibits the
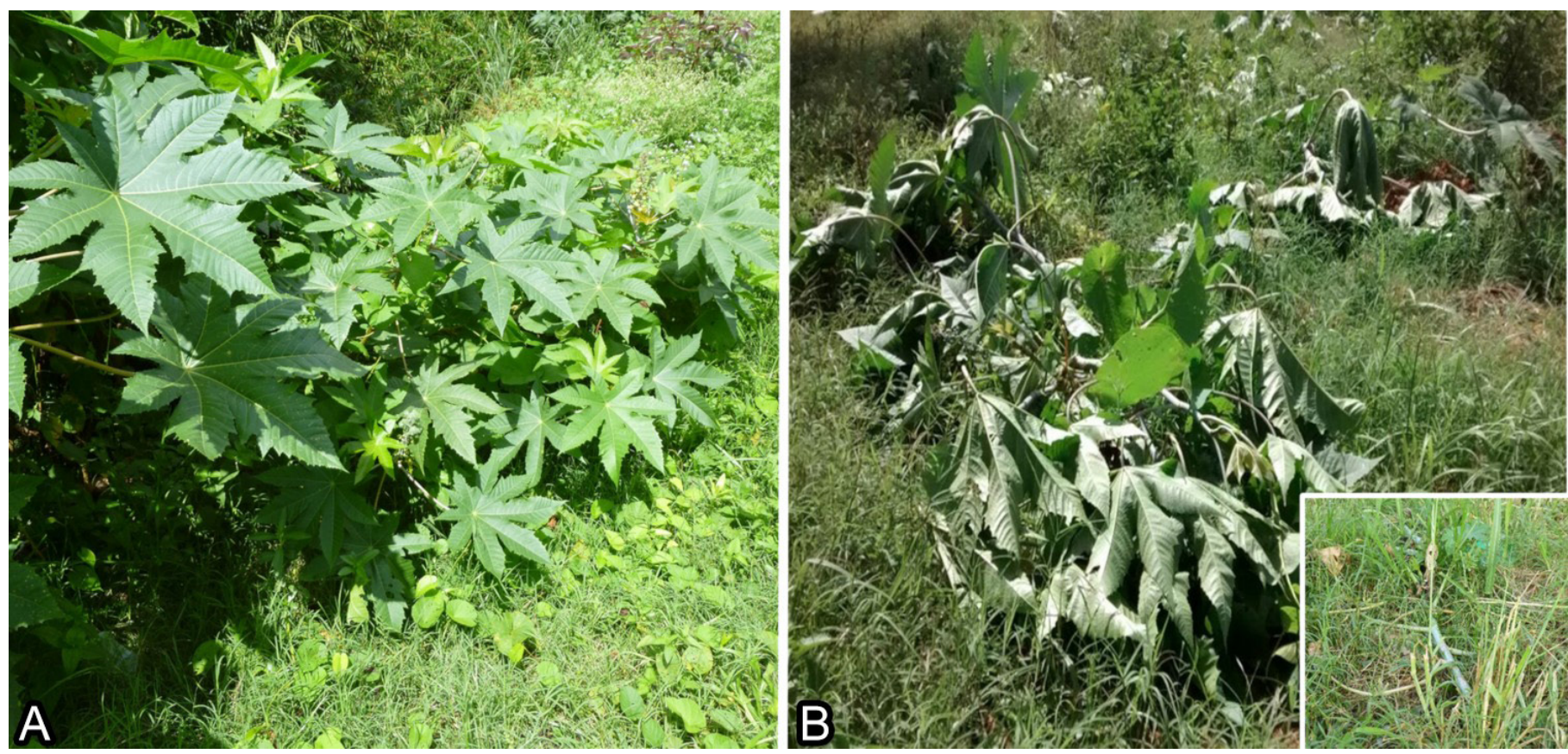

Fig.1. The pasture area was inspected and sprouts of Ricinus communis with evidence of being consumed were observed. 

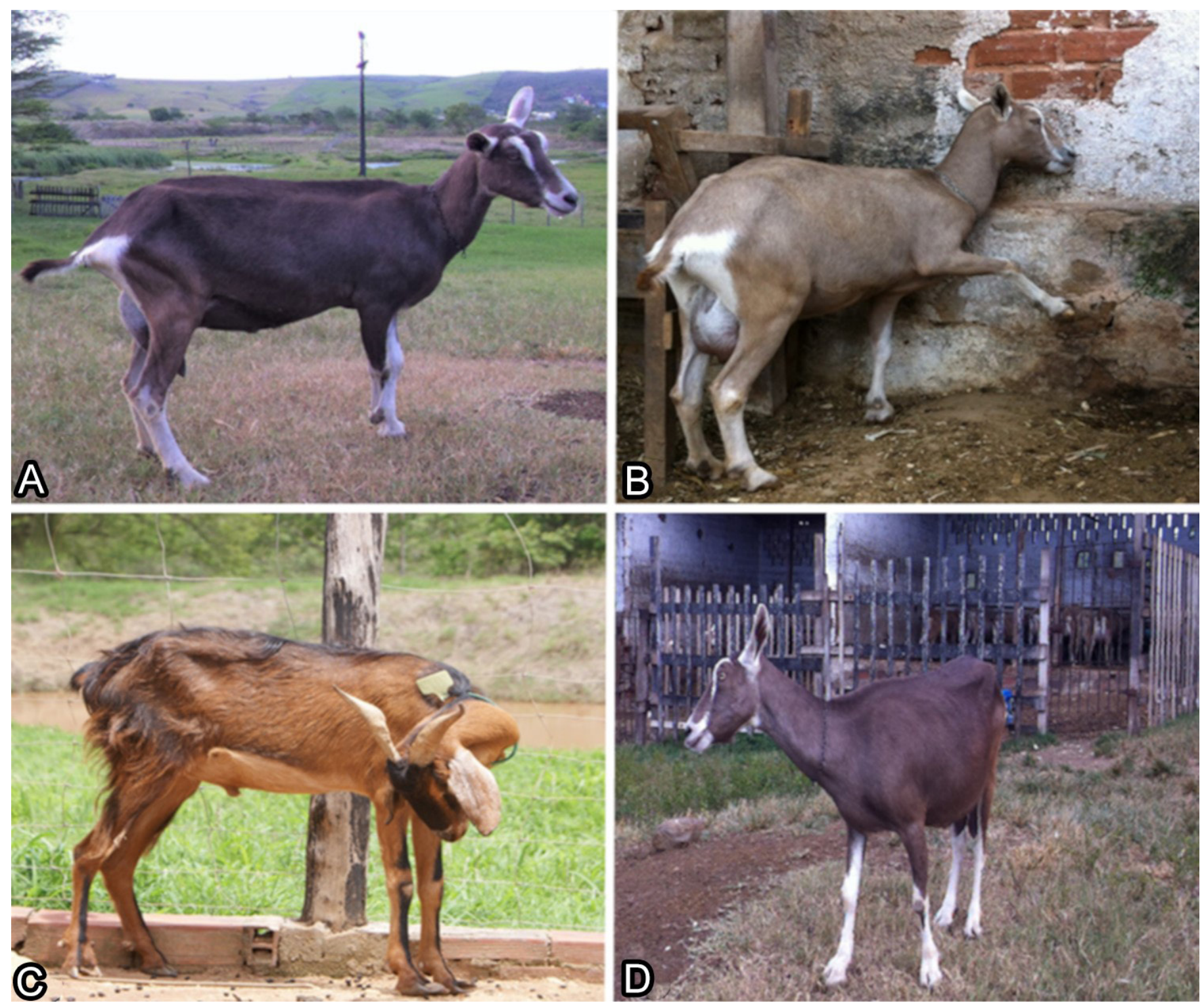

Fig.2. All goats in this lot were poisoned and more severely affected goats presented (A,B) dehydration, congestion of episcleral vessels, tachycardia, dyspnea, decreased free locomotor activity until severe ataxia (when standing the goats remained with the limbs crossed); (C,D) sialorrhea, depression, constant chewing movements, lateral deviation of head and neck, incoordination, staggering gait, abnormal postures and mild bloat.

action of metal-containing enzymes, especially cytochrome oxidase, resulting in the interruption of ATP production in mitochondria (Câmara et al. 2014). This mechanism is associated to cyanotic mucosa, nystagmus, head and eyelid tremors, incoordination followed by falls, lateral recumbency, opisthotonos and death. In Brazil, mainly in the northeastern region, most important cyanogenic plants reported causing outbreaks of poisoning were Anadenanthera colubrina var. cebil (Piptadenia macrocarpa), Cnidoscolus quercifolias (C. phyllacanthus), Manihot carthaginensis var glaziovii, Passiflora foetida, Piptadenia viriflora, Sorghum halepense and S. bicolor (Tokarnia et al. 2012, Câmara et al. 2014).

In cattle, the intense hunger is the main condition responsible for the ingestion of Ricinus communis and the acute poisonings (Albuquerque et al. 2014). The intense hunger seems not be the unique condition that facilitates the poisoning by $R$. communis leaves because in this outbreak, the goats were raised with enough pasture, not overcrowded and they had an adequate provision of water, mineral salt and commercial ration. The same situation was reported in sheep that ingested pruning waste containing $R$. communis (Bianchi et al. 2018). In another hand, withered leaves could concentrate more toxins and may be more palatable to ruminants (Tokarnia et al. 2012). In this situation, the presence of withered leaves in the pasture after the pruning could be a factor that facilitates the ingestion and the poisoning by the $R$. communis leaves in goats.

Doses of $10 \mathrm{~g} / \mathrm{kg}$ of fresh leaves of $R$. communis causes severe clinical picture in cattle and the lethal dose is $20 \mathrm{~g} / \mathrm{kg}$; but this dose must be ingested in a short period of time to 
cause death (Tokarnia et al. 1975, Döbereiner et al. 1981). For sheep, the lethal dose of fresh leaves is $30 \mathrm{~g} / \mathrm{kg}$, but in goats this dose and doses until $40 \mathrm{~g} / \mathrm{kg}$ just caused mild clinical signs. For goats the lethal dose of fresh leaves was not established (Bezerra \& Brito 1995). The main clinical signs observed in goats poisoned by $R$. communis consisted of a neurologic disease, with decreased free locomotor activity and severe ataxia, since they only consumed the leaves, which contains ricinine, an alkaloid that has typical CNS activity (Khafagy et al. 1983, Ferraz et al. 1999, Ohishi et al. 2014).

In a study with poisoned sheep by Ricinus communis, the clinical signs consisted in some neurological and digestive clinical picture and gross lesions consisted mainly in a severe gastroenteritis, cardiac haemorrhage and necrosis, hepatic necrosis and acute tubular necrosis in kidneys (Aslani et al. 2007). But these sheep ingested both leaves and seeds and because this, showed gross lesions mainly compatible by ricin toxicosis (Worbs et al. 2011, Tokarnia et al. 2012, Albuquerque et al. 2014). All other studies of poisoning by $R$. communis leaves in ruminants, including this report in goats, revealed no gross or microscopic lesions in CNS (Tokarnia et al. 1975, 2012, Döbereiner et al. 1981, Bezerra \& Brito 1995, Bianchi et al. 2018). But the clinical picture consisted of ataxia, depression, chewing movements, lateral deviation of head and neck, incoordination and staggering gait are probably caused by biochemical alterations in the cerebrum, cerebellum and brainstem (Riet-Correa et al. 2002) because in poisoned mice by ricinine, it was suggested that an increased release of glutamine in the cerebral cortex can be implicated in the genesis of the neurological clinical picture (Ferraz et al. 2002).

Ricinus communis is often cited by farmers as a cause of death, especially in cattle in northeastern Brazil and spontaneous poisoning is always associated with intense hunger (Albuquerque et al. 2014). In goats, the ingestion of leaves seems to be an unusual event, thus the poisoning is not common and occurred mainly due to accidental ingestion of pruning waste, as reported previously with other species of poisonous plants such as Nerium oleander and Kalanchoe blossfeldiana (Soto-Blanco et al. 2006, Mendonça et al. 2018). There is no specific therapy for poisoning by $R$. communis and for this reason, supportive and symptomatic treatment in all species is recommended (Albretsen et al. 2000, Albretsen 2003, Doan 2004) and should be based on the clinical signs. In years of severe drought in the semiarid northeastern region, prophylaxis consists of eradication of the plant or keeping the ruminants away from areas where there is a severe propagation of $R$. communis (Albretsen et al. 2000, Albretsen 2003, Doan 2004, Tokarnia et al. 2012).

Acknowledgements.- This work was supported by National Institute for Science and Technology for the Control of Plant Poisonings, National Council of Scientific and Technological Development (CNPq Grant: 573534/2008-0 and 309725/2015-1)

Conflict of interest statement.- The authors have no competing interest.

\section{REFERENCES}

Albretsen J.C. 2003. Lectins, p.406-408. In: Plumlee K.H. (Ed), Clinical Veterinary Toxicology. Mosby, St Louis.
Albretsen J.C., Gwaltney-Brant S.M. \& Khan S.A. 2000. Evaluation of castor bean toxicosis in dogs: 98 cases. J. Am. Anim. Hosp. Assoc. 36(3):229-233. <http://dx.doi.org/10.5326/15473317-36-3-229><PMid:10825094>

Albuquerque S.S.C., Rocha B.P., Albuquerque R.F., Oliveira J.S., Medeiros R.M.T., Riet-Correa F., Evêncio-Neto J. \& Mendonça F.S. 2014. Spontaneous poisoning by Ricinus communis (Euphorbiaceae) in cattle. Pesq. Vet. Bras. 34(9):827-831. <http://dx.doi.org/10.1590/S0100-736X2014000900004>

Al-Tamimi F.A. \& Hegazi A.E. 2008. A case of castor bean poisoning. Sultan Qaboos Univ. Med. J. 8(1):83-87. <PMid:21654963>

Armién A.G., D’Angelis F.H. \& Tokarnia C.H. 1996. Intoxicação experimental pelas sementes de Ricinus communis (Euphorbiaceae) em ovinos. Pesq. Vet. Bras. 16(4):99-106.

Aslani M.R., Maleki M., Mohri M., Sharifi K., Najjar-Nezhad V. \& Afshari E. 2007. Castor bean (Ricinus communis) toxicosis in a sheep flock. Toxicon 49(3):400-406. <http://dx.doi.org/10.1016/j.toxicon.2006.10.010> $<$ PMid:17157890>

Assis Júnior E.M., Fernandes I.M.D.S., Santos C.S., Mesquita L.X., Pereira R.A., Maracajá P.B. \& Soto-Blanco B. 2011. Toxicity of castor bean (Ricinus communis) pollen to honeybees. Agric. Ecosyst. Environ. 141(1/2):221 223. <http://dx.doi.org/10.1016/j.agee.2011.02.010>

Assis T.S., Medeiros R.M.T., Araújo J.A.S., Dantas A.F.M. \& Riet-Correa F. 2009 Intoxicações por plantas em ruminantes e equídeos no Sertão Paraibano. Pesq. Vet. Bras. 29(11):919-924. <http://dx.doi.org/10.1590/S0100736X2009001100010>

Berman P., Nizri S. \& Wiesman Z. 2011. Castor oil biodiesel and its blends as alternative fuel. Biomass Bioenerg. 35(7):2861-2866. <http://dx.doi. org/10.1016/j.biombioe.2011.03.024>

Bezerra M.J.G. \& Brito M.F. 1995. Intoxicação experimental pelas folhas de Ricinus communis (Euphorbiaceae) em ovinos e caprinos. Pesq. Vet. Bras. 15(1):27-34.

Bianchi M.V., Vargas T.P., Leite Filho L.V.R., Guimarães L.L.B., Heck L.C., Pavarini S.P. \& Driemeier D. 2018. Intoxicação espontânea por Ricinus communis em ovinos. Acta Scient. Vet. 46(1):1-4.

Bigi M.F., Torkomian V.L., Groote S.T., Hebling M.J., Bueno O.C., Pagnocca F.C., Fernandes J.B., Vieira P.C. \& Silva M.F. 2004. Activity of Ricinus communis (Euphorbiaceae) and ricinine against the leaf-cutting ant Atta sexdens rubropilosa (hymenoptera: Formicidae) and the symbiotic fungus Leucoagaricus gongylophorus. Pest Management Sci. 60(9):933-938. <http://dx.doi.org/10.1002/ps.892> <PMid:15382509>

Brito M.F. \& Tokarnia C.H. 1997. Intoxicação experimental pelas sementes trituradas de Ricinus communis (Euphorbiaceae) em coelhos. Pesq. Vet. Bras. 17(1):1-7.<http://dx.doi.org/10.1590/S0100-736X1997000100001>

Câmara A.C.L., Dalcin L. \& Soto-Blanco B. 2014. Patogênese, sinais clínicos e epidemiologia das intoxicações por plantas cianogênicas no nordeste brasileiro. Semina, Ciênc. Agrárias 35(4):1961-1972. <http://dx.doi org/10.5433/1679-0359.2014v35n4p1961>

De Paepe P., Gijsenbergh F., Martens F., Piette M. \& Buylaert W. 2005. Two fatal cases following ricin injection. Brit. J. Clin. Pharmacol. 59:125-126.

Dehority B.A. 1993. Laboratory Manual for Classification and Morphology of Rumen Ciliate Protozoa. CRC Press Inc., Florida. 96p.

Diniz L.L., Valadares Filho S.C., Oliveira A.S., Pina D.S., Lima da Silva N., Benedeti P.B., Baião G.F., Campos J.M.S. \& Valadares R.F.D. 2011. Castor bean meal for cattle finishing: 1, nutritional parameters. Livestock Sci. 135(2/3):153-167. <http://dx.doi.org/10.1016/j.livsci.2010.07.001>

Dirksen G. 1993. Sistema digestivo, p.166-228. In: Dirksen G., Gründer H.D. \& Stöber M. (Eds), Rosenberger Exame Clínico dos Bovinos. $3^{3}$ ed. Guanabara Koogan, Rio de Janeiro.

Doan L.G. 2004. Ricin: mechanism of toxicity, clinical manifestations and vaccine development. J. Toxicol. 42(2):201-208. <PMid:15214627> 
Döbereiner J., Tokarnia C.H. \& Canella C.F.C. 1981. Experimental poisoning of cattie by the pericarp of the fruit of Ricinus communis. Pesq. Vet. Bras. $1(3): 95-97$.

Ferraz A.C., Mangelucci M.E., Costa M.L., Batista I.R., Oliveira B.H. \& Cunha C. 1999. Pharmacological evaluation of ricinine, a central nervous system stimulant isolated from Ricinus communis. Pharm. Bioch. Behav. 63(3):367-375. <http://dx.doi.org/10.1016/S0091-3057(99)00007-6> $<$ PMid:10418776>

Ferraz A.C., Anselmo-Franci J.A., Perosa S.R., Castro-Neto E.F., Bellissimo M.I., Oliveira B.H., Cavalheiro E.A., Naffah-Mazzacoratti M.G. \& Cunha C. 2002. Amino acid and monoamine alterations in the cerebral cortex and hippocampus of mice submitted to ricinine-induced seizures. Pharmacol. Biochem. Behav 72(4):779-786. <http://dx.doi.org/10.1016/S00913057(02)00750-5><PMid:12062566>

Gowda N.K.S., Pal D.T., Bellur S.R., Bharadwaj U., Sridhar M., Satyanarayana M.L., Prasad C.S., Ramachandra K.S. \& Sampath K.T. 2009. Evaluation of castor (Ricinus communis) seed cake in the total mixed ration for sheep. J. Sci. Food Agric. 89(2):216-220. <http://dx.doi.org/10.1002/jsfa.3427>

Khafagy S.M., Mahmoud Y.A., Salam N.A.A. \& Mahmoud Z.F. 1983. Crystalline principles from the leaves of Ricinus communis. J. Drug Res. 14:189-194.

Lima R.L.S., Severino L.S., Sampaio L.R., Sofiatti V., Gomes J.A. \& Beltrão N.E.M. 2011. Blends of castor meal and castor husks for optimized use as organic fertilizer. Ind. Crops Products 33(2):364-368. <http://dx.doi. org/10.1016/j.indcrop.2010.11.008>

Lopes S.T.A., Biondo A.P.S. \& Santos A.P. 2007. Manual de Patologia Clínica Veterinária. 3aa ed. Departamento de Clínica de Pequenos Animais, UFSM, Santa Maria, p.5-45.

Lucas G.N. 2008. Plant poisoning in Sri Lankan children: a hospital based prospective study. Sri Lanka J. Child Health 35(4):111-124. <http://dx.doi. org/10.4038/sljch.v35i4.30>

Mello G.W.S., Oliveira D.M., Carvalho C.J.S., Pires L.V., Costa F.A.L., Riet-Correa F. \& Silva S.M.M. 2010. Plantas tóxicas para ruminantes e eqüídeos no Norte Piauiense. Pesq. Vet. Bras. 30(1):1-9. <http://dx.doi.org/10.1590/ S0100-736X2010000100001>

Mendonça F.S., Nascimento N.C.F., Almeida V.M., Braga T.C., Ribeiro D.P., Chaves H.A.S., Silva Filho G.B. \& Riet-Correa F. 2018. An outbreak of poisoning by Kalanchoe blossfeldiana in cattle in northeastern Brazil. Trop. Anim. Health Prod. 50(3):693-696. <http://dx.doi.org/10.1007/s11250-017-1465-7> $<$ PMid:29147934>

Miranda Neto E.G., Afonso J.A.B., Mendonça C.L. \& Almeida M.Z.P.R.B. 2005 Avaliação do comportamento clínico e das características do suco ruminal em caprinos com acidose lática induzida experimentalmente. Pesq. Vet. Bras. 25(2):73-78. <http://dx.doi.org/10.1590/S0100-736X2005000200002>

Nishiyama T., Oka H., Miyoshi M., Aibiki M., Maekawa S. \& Shirakawa Y. 2005. Case of accidental ingestion of caster beans: acute intoxication by ricin Chudoku Kenkyu 18(2):149-150. <PMid:16045176>
Ohishi K., Toume K., Arai M.A., Sadhu S.K., Ahmed F., Mizoguchi T., Itoh M. \& Ishibashi M. 2014. Ricinine: A pyridone alkaloid from Ricinus communis that activates the Wnt signaling pathway through casein kinase $1 \alpha$. Bioorganic Med. Chem. 22(17):4597-4601.<http://dx.doi.org/10.1016/j. bmc.2014.07.027><PMid:25124862>

Poli M.A., Roy C., Huebner K.D., Franz D.R. \& Jaax N.K. 2007. Ricin, p.323-335. In: Dembek Z.F. (Ed), Medical Aspects of Biological Warfare. 2nd ed. TMM Publications, Washington, DC.

Riet-Correa F., Riet-Correa G. \& Schild A.L. 2002. Importância do exame clínico para o diagnóstico das enfermidades do sistema nervoso em ruminantes e equídeos. Pesq. Vet. Bras. 22(4):161-168. <http://dx.doi.org/10.1590/ S0100-736X2002000400006>

Riet-Correa F., Medeiros R.M.T., Pfister J.A. \& Mendonça F.S. 2017. Toxic plants affecting the nervous system of ruminants and horses in Brazil. Pesq. Vet. Bras. 37(12):1357-1368. <http://dx.doi.org/10.1590/s0100736x2017001200001>

Silva D.M., Riet-Correa F., Medeiros R.M.T. \& Oliveira O.F. 2006. Plantas tóxicas para ruminantes e eqüídeos no Seridó Ocidental e Oriental do Rio Grande do Norte. Pesq. Vet. Bras. 26(4):223-236. <http://dx.doi.org/10.1590/ S0100-736X2006000400007>

Soto-Blanco B., Fontenele-Neto J.D., Silva D.M., Reis P.F. \& Nóbrega J.E. 2006. Acute cattle intoxication from Nerium oleander pods. Trop. Anim. Health Prod. 38(6):451-454. <http://dx.doi.org/10.1007/s11250-006-4400-x> <PMid:17243471>

Tokarnia C.H. \& Döbereiner J. 1997. Imunidade cruzada pelas sementes de Abrus precatorius e Ricinus communis em bovinos. Pesq. Vet. Bras. 17(1):25-35. <http://dx.doi.org/10.1590/S0100-736X1997000100005>

Tokarnia C.H., Döbereiner J. \& Canella C.F.C. 1975. Intoxicação experimental em bovinos pelas folhas de Ricinus communis. Pesq. Agropec. Bras. Série Vet. 10:17.

Tokarnia C.H., Brito M.F., Barbosa J.D., Peixoto P.V. \& Döbereiner J. 2012. Plantas Tóxicas do Brasil para Animais de Produção. $2^{\underline{a}}$ ed. Helianthus, Rio de Janeiro.

Upasani S.M., Kotkar H.M., Mendki P.S. \& Maheshwari V.L. 2003. Partial characterization and insecticidal properties of Ricinus communis L. foliage flavonoids. Pest Management Sci. 59(12):1349-1354. <http://dx.doi. org/10.1002/ps.767><PMid:14667057>

Visek W.J. 1984. Ammonia: its effects on biological systems, metabolic hormones, and reproduction. J. Dairy Sci. 67(3):481-498. <http://dx.doi. org/10.3168/jds.S0022-0302(84)81331-4><PMid:6371080>

Worbs S., Köhler K., Pauly D., Avondet M., Schaer M., Dorner M.B. \& Dorner B.G. 2011. Ricinus communis intoxications in human and veterinary medicine, a summary of real cases. Toxins 3(10):1332-1372. <http:// dx.doi.org/10.3390/toxins3101332><PMid:22069699> 